\title{
Study of flipped classroom model of college English class under the background of Mu
}

\author{
Yun ZHAO \\ Foreign Language School \\ Yunnan Technology and Business University \\ Kunming, 651700, China
}

\begin{abstract}
Flip classroom teaching, micro course and Mu class platform poses a severe challenge for college English public course. This paper studies the concept of flipped classroom model, success stories, we introduce the use of flipping the classroom teaching mode on college English public courses, build a learning support system, a single study design learning tasks and organization of teaching practice. Finally, analyzes and discuss potential advantages and limitations of classroom teaching mode of flipping English public courses in the college.
\end{abstract}

Keywords- flip the classroom; college English; Mu class

\section{INTRODUCTION}

In the development of educational technology and the popularity of smart mobile terminals, learners look forward that old courses have a new look. Teaching in a new era of information technology, higher education colleges' indispensable reforms should focus on foreign language teaching in order to explore the integration of the computer network as the core of modern information technology and foreign language courses in college. For 5,6-year-old who came into contacting with English, for post-90 students, PPT language, PPT plus textbook knowledge unidirectional instilling college English teaching is unlikely to lift their appetite. Coupled with flipping classroom teaching in schools it has been carried out in full swing, if college English course is at the stage of millet plus rifles, it will inevitably make the students have a sense of loss of retrogression, which makes them disappointed at university English course. Colleges and universities' foreign language teacher not only should understand the English itself, but also should be aware of modern information technology and the characteristics of the 90 students; the information technology in the English curriculum is to promote the teaching and learning process. Basic knowledge of English learner differences and limited classification teaching effectiveness of traditional classroom teaching presents a challenge. Because over the Primary English Teaching level there is a huge difference in students' English levels from different regions, there are big differences in teaching college English public and it has posed a serious challenge. Outstanding performance: teaching teachers 'organizations is always difficult to meet the needs of all students, and learners of teaching discontent have a direct impact on teachers' enthusiasm. Although our school is with a classification of teaching, but students are more willing to work with their classmates together in class, liquidity is very small. English courses are in urgent need of a breakthrough in the university to meet the student's individualized learning.

Flipped classroom teaching theoretical foundation, application and research status flipped classroom model is referred to as "students first prepared by a teacher or a third party's use of video self preset topic, and in the classroom it is in order to solve problems and practical form of the knowledge to use. "Flipped classroom is the theoretical basis - Benjamin Bloom's mastery learning theory. "Mastery learning" is a new type of individual teaching practice, and it is individualized instruction on the basis of collective teaching conducted. Just flip through the classroom teacher to help students to focus on the important points is not enough and we need to know and understand diagnostic tests students' knowledge to grasp the situation, to ask questions in class, answer the difficulty for students and help students to gain knowledge within technology.

\section{FEASIBILITY OF FLIPPING CLASSROOM TEACHING MODE IN COLLEGE ENGLISH PUBLIC COURSES}

Public college English classes have the basic conditions for carrying out flip classroom teaching, there is certain feasibility. First, the vast majority of college students mastered a certain IT capabilities, to hold and operate a smart phone, tablet PCs, notebook computers and other hardware facilities, school dormitories, libraries, classrooms and other places fiber optic cable, WIFI double coverage. Secondly, some teachers in college English teaching in the field of information technology have certain qualities; they are capable of making conventional learning resources, learning resources management and publishing tasks. Again, college English courses are with a strong practical, taskdriven for the most part, to carry out teaching activities of teaching methods. Fourth, some students have a certain amount of self-learning ability and self-management skills, and they are able to be completed in accordance with the requirements of teacher self-learning task.

\section{COLLEGE ENGLISH CAN LEVERAGE MOOC OR NOT}

$\mathrm{Mu}$-class information technology and teaching as highly integrated synthesizer, is a product of the most representative of educational technology development. According to the latest definition of the American Association for Educational Communications and Technology (AECT), educational 
technology is in ethics, through the creation, we use and manage technological processes and resources in order to promote learning and improve performance for targeted research and practice (Richey, 2008: twenty four). So, whether it is based on learning theory cMOOC Unicom, or xMOOC behavior based learning theory, the ultimate goal is to improve education and learning. University of College English as a compulsory public infrastructure has wide audience. How the College English Students really like building a lifelong benefit of quality courses, thereby it is better meet the needs of national economic and social development of personnel training, which is an important goal to further deepen the reform of college English courses (Wang Shou-ren, 2013: 9). Visible, objective connotation of English target demand for high quality teaching and MOOC is highly consistent. Therefore, college English should leverage MOOC. In terms of teaching and learning mode, MOOC represents a science-based learning model of welldesigned. It combines the use of the people, constructivism learning theory principles, procedures teaching and meaningful learning (Li Manli, 2013: 83). Compared with the traditional classroom, MOOC number in teaching, classroom space, motivation, learning the subject, interactive, curriculum design and evaluation of such links has essentially difference. "Placed upon the importance of the people teaching content," it essentially deconstructs the traditional classroom system of people face to face "teaching and learning behavior chain", and through process reengineering, reconstructed Internet-based interactive system (Zou Jingping, 2013: 72) is to achieve a joint platform, teachers, learners and learning resources of the four elements (Chen Bingbing, 2014: 39-40). This interaction model is a prerequisite for language learning to take place. Therefore, relatively speaking, MOOC has more considerable progress than existing national courses, video open class and resource sharing lessons on teaching function (Ying et al., 2013: 71-72).

\section{REFORM PRACTICE BASED ON MOOC FLIPPED CLASSROOM MODEL OF SCHOOL-BASED}

\section{A. teachers work}

Teachers work includes two aspects: MOOC curriculum design and resource development; classroom teaching design and evaluation activities. MOOC core curriculum is designed to teach video creation. Instructional video creations are with multiple modes, and this study is based on video lecture teaching unit model. Video is to explain the contents of the design highlights which include: English language knowledge, such as vocabulary, rhetorical methods, language skills and other techniques are to apply knowledge and crosscultural communication and learning strategies knowledge. Content arrangements use unit theme for the program and the text to simulate the teacher tutoring for a student's selflearning process. Each unit consists of 20 paragraphs about the video, between 3-6 minutes in length. Generally the first video of each article is the subject of mining, the next order of paragraphs is to explain the knowledge points. Most of the video has two or three questions at the end to encourage students to reflect summarize what they learn, and teachers can use these questions to check students' learning in the classroom situation.

\section{B. student's work}

MOOC students are in accordance with the requirements of self-study courses and flipped classroom learning, respectively. Students need to log in online courses at: http: / / mooc. bitmen. org /, after registration click Find courses and completing the self-study courses in accordance with the system unit task schedule requirements. The college English courses MOOC contents of each unit include three parts: video lectures: students can watch repeatedly learning; online homework: Students need complete before setting the date of submission; online discussions and progress query: Students will learn to communicate in doubt automatic check their learning progress. Edx course curriculum is based on platform, open source, from the experimental school schoolbased platform built from the transformation. In order to facilitate the movement of students to learn, students use the phone platform supporting two-dimensional code scanning APP by phone to complete the relevant mobile learning course content.

\section{ENVIRONMENTAL CHARACTERISTICS OF TEACHING ANALYSIS}

\section{A. Analysis of the current teaching model}

The current college English teaching model for the use of multimedia Chinese universities focus on teaching students to use the Internet and self-learning combined. This teaching model is that teachers will talk about making their own content into multimedia courseware, students under the guidance of teachers learn by watching multimedia courseware show content. Lower class students use their spare time to finish the job, and use spare time on a selflearning platform supporting materials to further consolidate or in-depth study. Compared with the traditional mode of teaching, the advantages of this mode is that the use of multimedia teaching can be maps, text, sound, image integration, so that teaching and learning activities have become more colorful, while blending knowledge and learning skills training and intellectual development from in a lively image, in order to stimulate students' interest in learning. Students use their spare time for self-learning mode to some extent; students can achieve personalized learning requirements and highlight the dominant position of the students. But the shortcomings of the current teaching model is obvious: First, when playing multimedia courseware it is like a flash movie that is over, there are no outstanding knowledge, students take notes to keep up with the speed of the teacher to play, so that students have a sense of frustration and the gradual loss enthusiasm for learning English; secondly, in the limited classroom time, students watch multimedia courseware and can not find the problem in a timely manner, but the teachers and the students themselves instill not well within the knowledge, the dominant position of the students did not really get reflect; third, self-learning students after school often is not enough 
due to learning and teaching platform supporting rich and diverse content, and they lack supervision and guidance of teachers and unrewarding, it is not truly personalized learning requirements of students. Therefore, in order to make more effective use of multimedia, students make what they learned internalized and truly personalized learning, and it requires more sophisticated, more scientific college English teaching mode.

\section{B. Produce and watch video hardware}

English teaching reform has been implemented, it is based on college English teaching mode multimedia and network self-learning platform in colleges and universities across the country and it has been basically established. Universities and students use computers, electronic reading room and penetration and there is already high self-learning platform, which provides the necessary foundation for the realization of hardware college English teaching classes based on micro flipped classroom model. The author of the teachers and students in the survey questionnaire, 100 percent of teachers and 71 percent of the students already have their own PC, $29 \%$ of students said that although there is no PC, but the electronic reading room and campus-based network of schools independent learning platform fully meet their extracurricular watch videos, micro-lesson learning requirements.

\section{CONCLUSIONS}

Flip has a college English classroom teaching in public through the use of the potential advantages of flipping the classroom teaching, students in extracurricular opportunity carry out a flexible learning, valuable classroom time can finally be used to practice the language, the teachers explain more targeted, more targeted, truly succinctly and training. The role of teachers and students has also undergone a change; the students are learning the subject, teachers help students to acquire knowledge.

Flip the higher classes in college English teaching in public exhibit limitations flipped classroom have high requirements for teachers and learners. In order to help students before class learning, teachers must build a good learning support system for learners and it can construct a convenient access to learning resources and exchange of virtual learning environment, but also set some guiding means and incentives to stimulate learners' enthusiasm.

Flip on the organization of college English classroom teaching college English flipped classroom proposal must take into account public college English class nature of the course, as well as non-English majors learn English characteristics, course load is not too large, there are concise package of learning materials, learning tasks moderate difficulty, focuses on the foundation. Flipping must be thorough, there are self-learning content, teachers can not explain the lesson again. Students would not have to leave the task of self-study jobs.

\section{References}

[1] Liu Changjiang. College English Classroom Context ecological imbalance in Information and Reconstruction[D]. Shanghai International Studies University,2013.

[2] Sui Xiaobing. College English Teaching Optimization [D] under the network environment. Shanghai International Studies University,2013.

[3] $\mathrm{Hu}$ Jiasheng.paradigm shift in language-based Educational Technology Construction [D]. Shanghai International Studies University,2012.

[4] Gu Shimin. Course factors College English Autonomous Learning promote research [D]. Shanghai International Studies University,2013.

[5] Liu Fang. Constructivism college English writing mode theory guidance Study [D] China University of Geosciences, 2009.

[6] Peng Shun Integrated Mode: Innovative College English Classroom Teaching Model [D] Hunan Normal University, 2008. 